\title{
Corneal calcification as a presenting and diagnostic sign in hyperparathyroidism
}

\author{
R. PORTER AND A. L. GROMBIE \\ University Department of Ophthalmology, Royal Victoria Infirmary, Newcastle-upon-Tyne
}

Walsh and Howard (1947) were the first to describe the deposition of calcium salts in the corneae of patients with hypercalcaemia due to hyperparathyroidism. This finding was later supported by Cogan, Albright, and Bartter (1948), and Walsh and Murray (1953) described a further series of patients. Since then no further reports have appeared in the literature on this subject apart from a case described by Berkow, Fine, and Zimmerman ( 1968 ) in which intracellular deposits of calcium were found in the eyes of a patient with secondary hyperparathyroidism.

In all the patients described in the studies mentioned above, the diagnosis of hyperparathyroidism had already been made and the corneal and conjunctival deposits were found by careful examination with a slit lamp. None of the patients was reported as having any ocular symptoms.

This paper reports four patients in whom the diagnosis of hyperparathyroidism was confirmed after the discovery of calcium deposits in the cornea. In all four patients red irritable eyes were among their presenting symptoms and three of them offered general diagnostic problems until the discovery of the corneal calcium deposits. The findings are summarized in the Table.

Table Clinical investigations in four patients

\begin{tabular}{|c|c|c|c|c|c|c|c|c|c|}
\hline $\begin{array}{l}\text { Case } \\
\text { no. }\end{array}$ & $\begin{array}{l}\text { Serum } \\
\text { Ca } \\
(m g . / \\
\text { I } 00 \mathrm{ml} .)\end{array}$ & $\begin{array}{l}\text { Serum } \\
\text { phosphate } \\
(\mathrm{mg} . / \\
\text { IOO } \mathrm{ml} .)\end{array}$ & $\begin{array}{l}\text { Serum } \\
\text { alkaline } \\
\text { phos- } \\
\text { phatase } \\
(I . U .)\end{array}$ & $\begin{array}{l}\text { Urea } \\
\text { (mg./ } \\
\text { I oo } m l .)\end{array}$ & $\begin{array}{l}\text { Intra- } \\
\text { venous } \\
\text { pyelogram }\end{array}$ & $\begin{array}{l}\text { Skeletal } \\
\text { survey }\end{array}$ & $\begin{array}{l}\text { Barium } \\
\text { meal }\end{array}$ & $\begin{array}{l}\text { Selenium } \\
\text { scan }\end{array}$ & Pathology \\
\hline I & $\begin{array}{l}\text { I I } \cdot 0 \\
\text { I I } \cdot 4 \\
\text { I I } \cdot \text { I }\end{array}$ & $\begin{array}{l}2 \cdot 4 \\
2 \cdot 6 \\
2 \cdot 5\end{array}$ & $5^{I}$ & 24 & Normal & Normal & Normal & Negative & $\begin{array}{l}\text { Primary } \\
\text { nodular } \\
\text { chief cell } \\
\text { hyper- } \\
\text { plasia }\end{array}$ \\
\hline 2 & $\begin{array}{l}\text { 1 } 3.6 \\
14.0 \\
13.9\end{array}$ & $\begin{array}{l}2 \cdot 4 \\
2 \cdot 5 \\
2 \cdot 3\end{array}$ & I I 7 & 44 & Normal & $\begin{array}{l}\text { Bone } \\
\text { cysts } \\
\text { Phalan- } \\
\text { geal } \\
\text { erosions }\end{array}$ & $\begin{array}{l}\text { Duodenal } \\
\text { ulcer }\end{array}$ & Negative & $\begin{array}{l}\text { Benign } \\
\text { adenoma }\end{array}$ \\
\hline 3 & $\begin{array}{l}14 \cdot 2 \\
14 \cdot 0 \\
12 \cdot 7\end{array}$ & $\begin{array}{l}3 \cdot 2 \\
3 \cdot 5 \\
3 \cdot 7\end{array}$ & I 10 & 80 & $\begin{array}{l}\text { Bilateral } \\
\text { nephro- } \\
\text { calcinosis }\end{array}$ & Normal & Normal & $\begin{array}{l}\text { Raised } \\
\text { count } \\
\text { right } \\
\text { side }\end{array}$ & $\begin{array}{l}\text { Benign } \\
\text { adenoma }\end{array}$ \\
\hline 4 & $\begin{array}{l}\text { I } 3 \cdot 8 \\
\text { I I } \cdot 7 \\
\text { I I } \cdot 2\end{array}$ & $\begin{array}{l}3 \cdot 4 \\
3 \cdot 2 \\
3 \cdot 4\end{array}$ & 80 & 156 & Normal & Normal & $\begin{array}{l}\text { Duodenal } \\
\text { ulcer }\end{array}$ & Negative & $\begin{array}{l}\text { Hyper- } \\
\text { plasia? } \\
\text { secondary }\end{array}$ \\
\hline
\end{tabular}




\section{Case reports}

Case I, a 57-year-old man, presented with an 8-month history of photophobia and irritation, especially in the right eye.

\section{Examination}

The visual acuity was $6 / 6$ and $\mathrm{N}_{5}$ unaided in both eyes but marked bilateral band-shaped keratopathy was most noticeable in the centre of the cornea but tailed off at the limbus (Figure). No other abnormality was found.

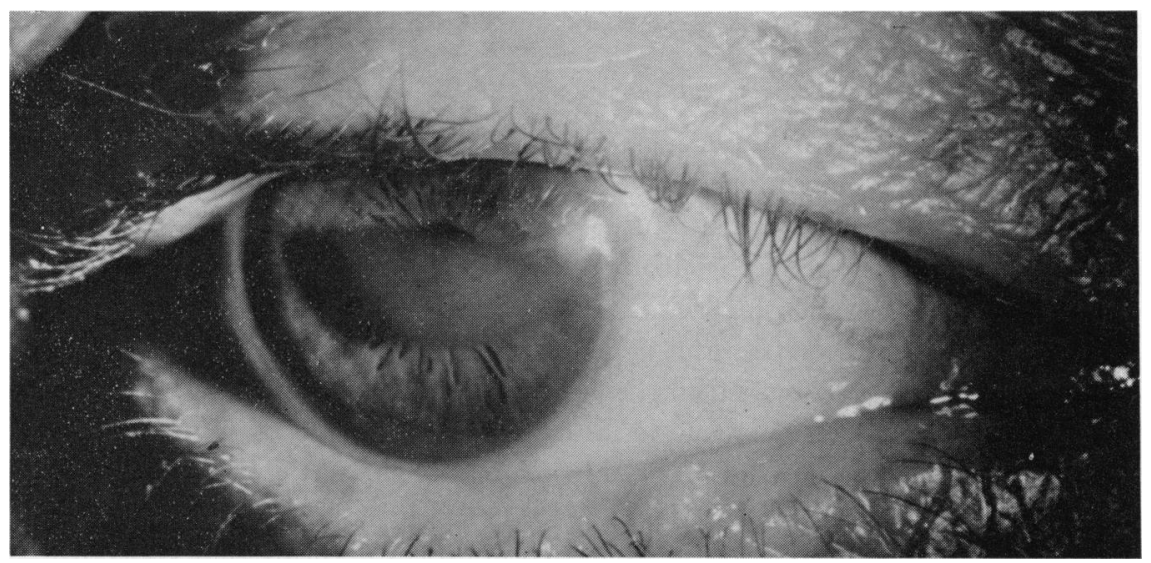

FIGURE Centrally placed corneal deposits in Case I

Serial fasting serum calcium estimations were I I $\cdot 0, I_{I} \cdot 4$, and II $\cdot \mathrm{I}_{\mathrm{mg}}$. per $\mathrm{I}$ oo $\mathrm{ml}$. respectively. Total serum proteins and electrophoresis were normal as were intravenous pyelogram, renal function, skeletal survey, and parathyroid selenium scan. The parathormone levels were slightly raised.

\section{Diagnosis}

Primary hyperparathyroidism.

\section{Operation}

The parathyroid glands were all found to be enlarged. Three were removed and histology showed primary nodular chief cell hyperplasia.

Result

Postoperatively the serum calcium levels returned to normal but after observation for $2 \frac{1}{2}$ years the corneal deposits although not increased are unchanged.

Case 2, a 5-year-old man, came to the eye department complaining of red irritable eyes. He had been investigated for attacks of ureteric colic io years before, but no abnormality had been found and the attacks had settled. He had developed attacks of abdominal pain 3 years before and a barium meal had confirmed the presence of duodenal ulcer which had eventually required surgical treatment with a vagotomy and pyloroplasty. This had relieved his symptoms until recently when he was once more complaining of abdominal pain.

\section{Examination}

The unaided visual acuity was $6 / 12$ in the right eye and 6/6 in the left and both conjunctivae were markedly injected with early band-shaped keratopathy confined mainly to the medial and lateral 
limbus in both eyes. There was no other ocular abnormality and general examination revealed only epigastric tenderness.

Serial fasting serum calcium estimations were $13.6,14 \cdot 0$, and $13.8 \mathrm{mg} / / 100 \mathrm{ml}$. respectively. Urinary calcium excretion was $369 \mathrm{mg}$. in $24 \mathrm{hrs}$. A skeletal survey showed numerous bone cysts and phalangeal erosions, but renal function tests, intravenous pyelogram, and selenium scan were normal.

\section{Operation}

A large adenoma of the lower right parathyroid was removed and this diagnosis was confirmed histologically.

Result

Postoperatively the patient was much improved and in particular the ocular injection and irritation disappeared, but despite this after 4 years of observation the corneal deposits remain unchanged.

Case 3, a 47-year-old female, presented with a 2-year history of increasing shortness of breath and lethargy complicated in the last 6 weeks with swelling of the ankles. She also had a I month's history of red irritable eyes.

\section{Examination}

She was hypertensive with early signs of cardiac decompensation. The visual acuity was $6 / 6$ in both eyes and she had early bilateral band-shaped keratopathy with early hypertensive retinopathy.

Serial fasting serum calcium estimations were $14^{\cdot 2}, 14^{\circ} 0$, and $12 \cdot 7 \mathrm{mg} . / 100 \mathrm{ml}$. respectively.

Urinary calcium excretion was $326 \mathrm{mg}$. in 24 hours.

Renal function tests were slightly impaired and an intravenous pyelogram showed bilateral renal calculi but a general skeletal survey was normal. A selenium scan showed an increased count rate on the right side of the neck.

\section{Operation}

A large adenoma of the lower right parathyroid was removed and histology showed it to be benign.

Result

The ocular irritation disappeared some weeks postoperatively and the renal calculi appeared to regress, but 3 years later the corneal deposits had not decreased.

Case 4, a 54-year-old man, presented complaining of increasing lassitude, fainting attacks, and painful eyes.

\section{Examination}

The visual acuity was $6 / 6$ in both eyes and the only abnormal physical findings were bilateral bandshaped keratopathy causing injected eyes.

Serial fasting serum calcium estimations were found to be $\mathrm{I} 3 \cdot 8$, i $\cdot 7$, and I I $\cdot 2 \mathrm{mg}$./ $100 \mathrm{ml}$. respectively. Renal function tests were impaired with a blood urea of $156 \mathrm{mg}$./ $100 \mathrm{ml}$; ; this was associated with persistent proteinuria and coliform organisms were consistently cultured from urine specimens. Intravenous pyelograms and retrograde pyelograms were normal, as was a skeletal survey which in particular showed no signs of nephrocalcinosis.

\section{Operation}

The parathyroid glands were found to be enlarged and two were removed, but histology showed the enlargement to be due to simple hyperplasia. At this stage the diagnosis was one of secondary hyperparathyroidism following chronic renal impairment, but postoperatively the serum calcium fell to normal and the renal function markedly improved so that the possibility of primary hyperparathyroidism was reconsidered. 
Result

The ocular discomfort lessened postoperatively but again after 6 years the calcium deposits were unchanged.

\section{Discussion}

Corneal calcification is well known to occur in cases of hyperparathyroidism (Walsh and Murray, I953; Cogan and others, 1948) and in other systemic conditions producing an alteration in the calcium and phosphate metabolism, such as sarcoidosis (Walsh and Murray, I953; Crick, Hoyle, and Smellie, I96I), vitamin D intoxication (Howard and Meyers, I948; Leira, I954), and chronic renal failure (Berlyne, I968; Porter and Crombie,. I972).

These four cases, which were collected from a group of eighty patients with hyperparathyroidism, show that this uncommon condition may present with ocular signs and symptoms which ultimately suggest the diagnosis. In cases of chronic renal failure with ocular vy calcium deposits, Porter and Crombie (1973) have shown that the majority of patients who receive a donated kidney will show gradual regression of these deposits once the donated of kidney has permanently returned the calcium and phosphate metabolism to normal. 은 In this respect the corneal deposits of the hyperparathyroid patients differ; having been $\vec{c}$ observed for periods varying from I to 6 years after their surgical cure, the deposits remain $\mathbb{D}$ unchanged. Berkow and others (1968) have suggested that these deposits also differ in respect of the position in which they are deposited. They have shown in one patient with secondary hyperparathyroidism that calcium salts are deposited intracellularly as opposed to the extracellular deposition in patients with renal failure. However, despite the persistence of these deposits, all four patients reported a disappearance of the ocularf. symptoms within a few months of operation.

\section{Summary}

Four cases of hyperparathyroidism are described in which corneal calcification was a presenting and ultimately diagnostic clinical sign.

We are grateful to Prof. I. Johnson for permission to examine patients under his care and to Mr. D. Britton for his helpful information.

\section{References}

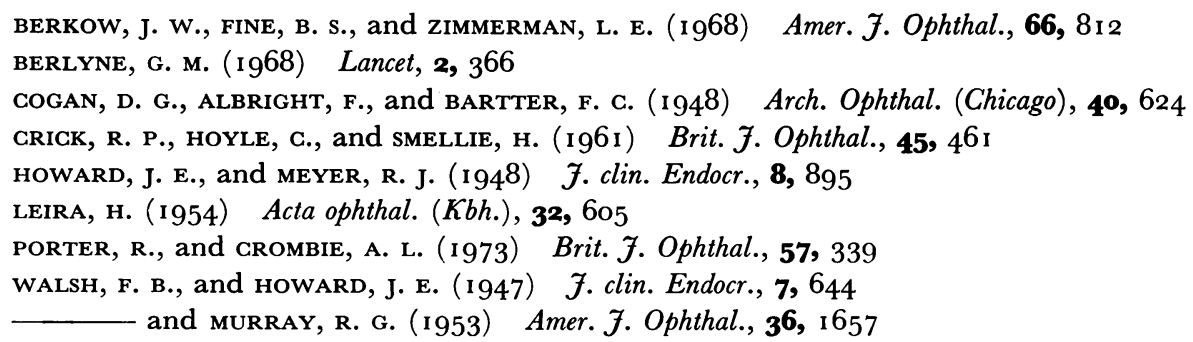

